\title{
Bacteriological diagnosis of $\beta$-hemolytic streptococci of the upper respiratory tract
}

\author{
Alina Borcan ${ }^{1,2^{*}}$, Olga Dorobăț ${ }^{2}$, Ioana Bădicuț ${ }^{1,2}$, Daniela Tălăpan ${ }^{1,2}$, Mariana Radut ${ }^{2}$, Mona Popoiu², \\ Anca Munteanu ${ }^{3}$, Alexandru Rafila ${ }^{1,2}$ \\ From The 10th Edition of the Scientific Days of the National Institute for Infectious Diseases "Prof Dr Matei \\ Bals" \\ Bucharest, Romania. 15-17 October 2014
}

\section{Background}

Beta-hemolytic streptococci are major human pathogens associated with local or systemic invasion and poststreptococcal immune disorders. We performed a comparison between bacitracin and latex agglutination test for the identification of beta-hemolytic streptococci. We assessed resistance patterns to erythromycin/clindamycin.

\section{Methods}

Between January 12014 - July 15 2014, 5038 throat swabs were sampled from patients hospitalized in INBI Matei Balş according to standard methods. All beta-hemolytic streptococci suspected colonies were tested with bacitracin $(0.04 \%)$ disks and we used the latex agglutination kit Omega Latex Diagnostic Avipath Strep. Erythromycin resistance testing was performed by disc $2 \mu \mathrm{g}$ Oxoid and clindamycin $2 \mu \mathrm{g}$ Oxoid on the blood $\mathrm{M}-\mathrm{H}$ medium.

\section{Results}

There were 460 isolates of beta-hemolytic streptococci, bacitracin test was positive for 373 (92.75\%). From 87 negative bacitracin test left streptococci, with latex agglutination test, 18 (20.68\%) were identified as Streptococcus pyogenes (group A) and 69 (79.32\%) were group C, G, B, F. Streptococcus pyogenes had $8.95 \%$ resistance to erythromycin, group $\mathrm{C}$ streptococci had $2.12 \%$, and group G 45.45 . From strains with resistance to erythromycin $75.6 \%$ were with inducible resistance to clindamycin and $17.07 \%$ had a constitutive one.

\section{Conclusion}

Latex agglutination is a preferable alternative to bacitracin testing, providing a definite grouping result.

\footnotetext{
* Correspondence: borcanalinamaria@yahoo.com

${ }^{1}$ Carol Davila University of Medicine and Pharmacy, Bucharest, Romania
}

Full list of author information is available at the end of the article
Resistance of Streptococcus pyogenes to erythromycin was $8.95 \%$ compared with group $\mathrm{G}$ which had a resistance of $45.45 \%$.

\section{Authors' details}

${ }^{1}$ Carol Davila University of Medicine and Pharmacy, Bucharest, Romania. ${ }^{2}$ National Institute for Infectious Diseases "Prof. Dr. Matei Balş", Bucharest, Romania. ${ }^{3}$ National Institute of Public Health, Bucharest, Romania.

Published: 15 October 2014

doi:10.1186/1471-2334-14-S7-P9

Cite this article as: Borcan et al.: Bacteriological diagnosis of

$\beta$-hemolytic streptococci of the upper respiratory tract. BMC Infectious

Diseases 2014 14(Suppl 7):P9.
Submit your next manuscript to BioMed Central and take full advantage of:

- Convenient online submission

- Thorough peer review

- No space constraints or color figure charges

- Immediate publication on acceptance

- Inclusion in PubMed, CAS, Scopus and Google Scholar

- Research which is freely available for redistribution
() Biomed Central 